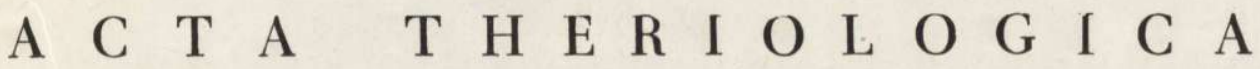 \\ VOL. XI, 2: $41-54$. \\ BIAŁOWIEŻA \\ 30.X.1966
}

Lucjan SY C H

\section{Correlation of Tooth Measurements in Leporids. \\ On the Significance of the Coefiicient of Correlation in the Studies of Microevolution}

[With 20 Figs. \& 3 Tables]

A comparison was made between the correlation patterns obtained through the calculation of coefficients of correlation ( $r$ and $z$ of $\mathrm{F}$ is h e r) for the measurements of cheek teeth in Lepus europaeus $\mathrm{P}$ a 11 a s, Lepus timidus Linnae us from the Arkhangel'sk and Vladivostok regions, Oryctolagus cuniculus $\mathrm{L}$ in $\mathrm{n}$ a e $\mathrm{us}$ and extinct Hypolagus brachygnathus $\mathrm{K}$ or mos from the upper Pliocene and lower Pleistocene. The highest correlations were found between the measurements of the middle teeth of both the upper and the lower row $\left(\mathrm{P}_{4}, \mathrm{M}_{1}, \mathrm{M}_{2}\right.$ and $\left.\mathrm{P}^{3}, \mathrm{P}^{4}, \mathrm{M}^{1}\right)$. The taxonomically important teeth $\mathrm{P}_{3}$ and $\mathrm{P}^{2}$ show comparatively low correlations with the other, even neighbouring, teeth. In the recent species some correlations were found between the widths of $\mathrm{M}_{2}$ and $\mathrm{M}_{3}$, but none at all between their lengths. No correlation exists between these teeth in Hypolagus. Despite the fact that the teeth of the species under study are very much alike, with the exception of $\mathrm{P}_{3}$ and $\mathrm{P}^{2}$, their correlation patterns differ considerably. Differences were demonstrated even between geographically remote populations of Lepus timidus from the Arkhangel'sk and Vladivostok regions. The structure of a correlation pattern may vary with time: Hypolagus brachygnathus from the first interglacial from Kadzielnia in Kielce showed evident changes in relation to that from the upper Pliocene of Rebielice Królewskie. The changes in the distribution of correlations are acompanied by an increase in their value. It seems as well that it is possible to establish the taxonomically important measurements by help of the coefficients of correlation grouped in pleiades. These measurements would be non-correlated or only slightly related directly with the other measurenents. The study of microevolutionary changes is possible in functionally related and, at the same time, highly correlated groups. 


\section{INTRODUCTION}

The existence of definite relations between the sizes of different parts of an organism is an almost obvious fact in the morphology of vertebrates. The constancy of mutual proportions of particular parts of body and especially that of skeletal elements in the same species or in groups of species standing close to it, is of essential importance, among others, in taxonomy as well as for the reconstruction of fossil forms. Generally speaking, the constancy of the proportions is due to the mutual relations, that is, the interdependence of the corresponding values. Correlation may be higher or lower or even quite lacking between some skeletal parts.

As will be seen from the studies carried out by Whitelay \& $\mathrm{Pe}$ a rs on (1900) on the degree of correlation of some measurements of the human hand, the nearer the bones concerned lie each other, the more correlated are their measurements. S i m p s on et al. (1960) found a high degree of interdependence of the measurements of two neighbouring teeth $\left(\mathrm{P}_{4}\right.$ and $\left.\mathrm{M}_{1}\right)$ in the fossil species of the genus Phenacodus $\mathrm{C}$ op e. The regularity with which the correlation increases, as the parts in question approach each other, has been called the "rule of neighbourhood". The studies on the correlations of the measurements of teeth in different species of mammals ( $K u r t$ é $n$, 1953) showed that the height of the coefficient of correlation $r$ may take various values for the same pairs of characters (tooth measurements) in different species. This fact induced the above-mentioned author to assume the conception of the so-called "genetic fields of growth" controlled in the course of growth of the organism by sets of polymeric genes.

Although the genic mechanism which brings about the formation of correlations is not known, the constant effect of its activity in a species suggests the existence of a pattern, according to which the relations between the characters are modified. It has already been ascertained that this pattern may be different even in species having very similar teeth (Kurtén, 1953; Sych, 1965). When using the term of correlation patterns, one should keep in mind that it is a kind of abstract models depending on the conventionality of measurements made on the dentition.

The objective of the present work is to compare the correlation patterns for the dentition of a few modern and one iossil species of the Leporidae and to analyse the correlations from the point of view of geographical and evolutionary variation and on account of their usefulness for taxonomic purposes. 


\section{MATERIAL AND METHOD}

The measurements of teeth analysed were derived from a series of skulls of the following species:

Lepus europaeus $\mathrm{P}$ a 11 a s, $1778-32$ specimens from the northern regions of Poland; Lepus timidus Lin na e us, $1758-24$ specimens from the Vladivostok region; Lepus timidus L in n a u s, $1758-24$ specimens from the Arkhangel'sk region; Oryctolagus cuniculus Linnaeus, $1758-22$ specimens from the central and northern parts of Poland.

In addition, 2 series of mandibles of the fossil species Hypolagus brachygnathus $\mathrm{K}$ ormos, 1934 from 2 faunas differing in geolcgical age were used: from Rębielice Królewskie in the Klobuck District (older upper Pliocene) - 18 specimens, and from Kadzielnia in Kielce (early Pleistocene, the beginning of the Günz-Mindel interglacial) -28 specimens.

The use of the specimens from Rębielice Królewskie for this study was possible owing to the acquisition of new fossil materials from this locality in the recent years.

Cheek teeth of the lower and upper rows in the modern material and those of the lower row only in the fossil material, in which a small number of specimens made it impossible to use the data concerning the upper dentition for calculation, were measured.

All the specimens constituted more or less homogeneous material in so far as their individual age was concerned. The material consisted of skulls of adult specimens in which the process of growth was, as a rule, completed.

Teeth were measured, using dividers and vernier calipers, to an accuracy of $0.1 \mathrm{~mm}$. The measurements included the greatest length of crown (front-rear) of all the teeth, the greatest width of trigonid on the lower teeth, and the greatest width (along the medio-lateral line) of the upper teeth. Coefficients of correlation were calculated for all the possible combinations of pairs in the lower row of cheek teeth (10 correlative pairs) and for all the possible combinations of pairs in the upper row of cheek teeth. The coefficients of correlation $r$ were converted to the values $z$ by the method of Fisher in order to compare various species.

I am greatly indebted to Prof. W. Heptner of the Zoological Museum of the Lomonosov University in Moscow, to Dr. K. C a b o ń-R a c z y ńs k a of the Mammals Research Institute at Białowieża, and to Dr. W. Empel of the Departament of Animal Anatomy, Agricultural University, Warsaw, for throwing their collections open to me during the present work.

\section{RESULTS}

The coefficients of correlation obtained are offered in Tables $1-3$. The values $z$ corresponding to the coefficients of correlation and representing statistically significat correlations are given in the form of histograms (Figs. $1-20$ ) so as to facilitate comparison.

\section{Height of Correlation and the "Rule of Neighbourhood"}

The rule of neighbourhood according to which the strongest correlations are between the neighbouring teeth, was confirmed in all the species 
Table 1.

Coefficients $r$ and $z$ of correlation between measurements of the upper cheek teeth.

\begin{tabular}{|c|c|c|c|c|c|c|c|c|}
\hline & \multicolumn{2}{|c|}{$\begin{array}{l}\text { L. timidus } \\
\text { Arkhangelsk }\end{array}$} & \multicolumn{2}{|c|}{$\begin{array}{l}\text { L. timidus } \\
\text { Vladivostok }\end{array}$} & \multicolumn{2}{|c|}{ L. europaeus } & \multicolumn{2}{|c|}{ O. cuniculus } \\
\hline & $r$ & $z$ & $r$ & $z$ & $r$ & $z$ & $r$ & $z$ \\
\hline $\mathrm{P}^{2}-\mathrm{P}^{3}$ & 0.11 & 0.110 & 0.47 & 0.510 & -0.19 & 0.192 & 0.56 & 0.633 \\
\hline $\mathrm{P}^{2}-\mathrm{P}^{4}$ & 0.05 & 0.050 & 0.39 & 0.412 & -0.24 & 0.245 & 0.40 & 0.424 \\
\hline $\mathrm{P}^{2}-\mathrm{M}^{1}$ & 0.17 & 0.171 & 0.11 & 0.110 & -0.28 & 0.288 & 0.21 & 0.213 \\
\hline $\mathrm{P}^{2}-\mathrm{M}^{2}$ & 0.01 & 0.010 & 0.09 & 0.090 & -0.17 & 0.172 & 0.37 & 0.388 \\
\hline $\mathrm{P}^{2}-\mathrm{M}^{3}$ & -0.15 & 0.151 & -0.12 & 0.121 & -0.07 & 0.070 & 0.12 & 0.121 \\
\hline $\mathrm{P}^{3}-\mathrm{P}^{4}$ & 0.95 & 1.832 & 0.90 & 1.472 & 0.85 & 1.256 & 0.81 & 1.127 \\
\hline $\mathrm{P}^{3}-\mathrm{M}^{1}$ & 0.81 & 1.127 & 0.78 & 1.045 & 0.82 & 1.157 & 0.64 & 0.758 \\
\hline $\mathrm{P}^{3}-\mathrm{M}^{2}$ & 0.44 & 0.472 & 0.50 & 0.549 & 0.48 & 0.523 & 0.67 & 0.811 \\
\hline $\mathrm{P}^{3}-\mathrm{M}^{3}$ & 0.11 & 0.110 & -0.15 & 0.151 & -0.05 & 0.050 & -0.19 & 0.192 \\
\hline $\mathrm{P}^{4}-\mathrm{M}^{1}$ & 0.92 & 1.589 & 0.92 & 1.589 & 0.78 & 1.045 & 0.72 & 0.908 \\
\hline $\mathrm{P}^{4}-\mathrm{M}^{2}$ & 0.46 & 0.497 & 0.58 & 0.662 & 0.23 & 0.234 & 0.71 & 0.887 \\
\hline $\mathrm{P}^{4}-\mathrm{M}^{3}$ & 0.02 & 0.020 & -0.12 & 0.121 & -0.06 & 0.060 & -0.04 & 0.040 \\
\hline $\mathrm{M}^{1}-\mathrm{M}^{2}$ & 0.69 & 0.848 & 0.65 & 0.775 & 0.72 & 0.908 & 0.72 & 0.908 \\
\hline $\mathrm{M}^{1}-\mathrm{M}^{3}$ & 0.09 & 0.090 & 0.07 & 0.070 & 0.03 & 0.030 & -0.19 & 0.192 \\
\hline \multirow[t]{2}{*}{$\mathrm{M}^{2}-\mathrm{M}^{3}$} & 0.20 & 0.203 & 0.02 & 0.020 & 0.11 & 0.110 & -0.16 & 0.161 \\
\hline & & & w i & d $\quad t$ & h & & & \\
\hline $\mathrm{P}^{2}-\mathrm{P}^{3}$ & 0.60 & 0.693 & 0.59 & 0.678 & 0.12 & 0.120 & 0.48 & 0.523 \\
\hline $\mathrm{P}^{2}-\mathrm{P}^{4}$ & 0.17 & 0.171 & 0.17 & 0.171 & 0.14 & 0.141 & 0.05 & 0.050 \\
\hline $\mathrm{P}^{2}-\mathrm{M}^{1}$ & 0.07 & 0.070 & -0.10 & 0.100 & 0.04 & 0.040 & 0.11 & 0.110 \\
\hline $\mathrm{P}^{2}-\mathrm{M}^{2}$ & 0.11 & 0.110 & -0.07 & 0.070 & 0.17 & 0.172 & 0.08 & 0.080 \\
\hline $\mathrm{P}^{2}-\mathrm{M}^{3}$ & -0.20 & 0.203 & 0.05 & 0.050 & 0.08 & 0.080 & 0.09 & 0.090 \\
\hline $\mathrm{P}^{3}-\mathrm{P}^{4}$ & 0.60 & 0.693 & 0.88 & 1.376 & 0.65 & 0.775 & 0.60 & 0.693 \\
\hline $\mathrm{P}^{3}-\mathrm{M}^{1}$ & 0.71 & 0.886 & 0.80 & 1.099 & 0.38 & 0.400 & 0.52 & 0.576 \\
\hline $\mathrm{P}^{3}-\mathrm{M}^{2}$ & 0.40 & 0.424 & 0.43 & 0.460 & 0.32 & 0.332 & 0.17 & 0.172 \\
\hline $\mathrm{P}^{3}-\mathrm{M}^{3}$ & 0.06 & 0.060 & -0.01 & 9.010 & 006 & 0.060 & 0.20 & 0.203 \\
\hline $\mathrm{P}^{4}-\mathrm{M}^{1}$ & 0.94 & 1.738 & 0.70 & 0.867 & 0.90 & 1.472 & 0.95 & 1.832 \\
\hline $\mathrm{P}^{4}-\mathrm{M}^{2}$ & 0.48 & 0.523 & 0.61 & 0.709 & 0.78 & 1.045 & 0.40 & 0.424 \\
\hline $\mathrm{P}^{4}-\mathrm{M}^{3}$ & 0.13 & 0.131 & -0.08 & 0.080 & 0.20 & 0.203 & 0.17 & 0.172 \\
\hline $\mathrm{M}^{1}-\mathrm{M}^{2}$ & 0.82 & 1.157 & 0.87 & 1.333 & 0.85 & 1.256 & 0.91 & 1.528 \\
\hline$M^{1}-M^{3}$ & -0.20 & 0.203 & 0.07 & 0.070 & -0.07 & 0.070 & -0.08 & 0.080 \\
\hline $\mathrm{M}^{2}-\mathrm{M}^{3}$ & 0.16 & 0.161 & 0.19 & 0.192 & 0.12 & 0.121 & 0.12 & 0.121 \\
\hline
\end{tabular}

examined in general outlines only. The strongest correlations were found between the measurements of the middle teeth of both the upper and the lower row: $\mathrm{P}_{3}^{3}, \mathrm{P}^{4}, \mathrm{M}^{2}$ and $\mathrm{P}_{4}, \mathrm{M}_{1}, \mathrm{M}_{2}$. The length of extreme $\mathrm{P}_{3}$ does not show a very high degree of correlation with the length of $\mathrm{P}_{4}$; in the case of Lepus timidus from the Vladivostok region there is no correlation at all. Similarly, the width of $\mathrm{P}_{3}$ is in a great degree 
Table 2.

Coefficients $r$ and $z$ of correlation between measurements of the lower cheek teeth.

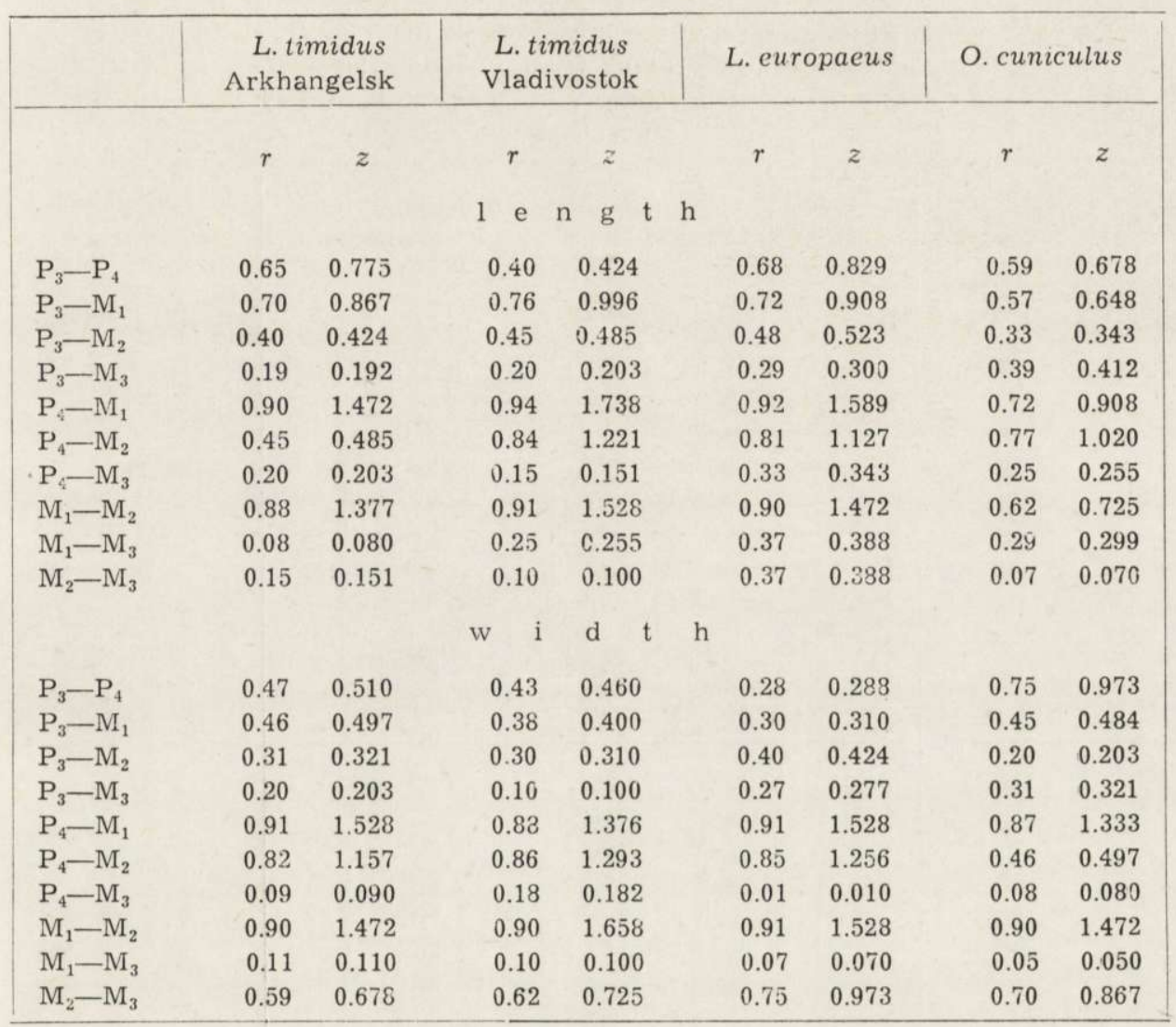

independent of the other measurements. High correlation can be found here only in Oryctolagus cuniculus. The length of extreme $\mathrm{P}^{2}$ also turns out highly independent of the length of $\mathrm{P}^{3}$. The correlation between these teeth was found only in their widths in Lepus timidus.

The complete lack of connections between the last two teeth of the lower row, $\mathrm{M}_{2}$ and $\mathrm{M}_{3}$, in the majority of the species examined deserved special attention. Here, correlation occurred only between the widths of teeth and, even then, only in recent species. In Hypolagus brachygnathus it was wanting at all.

\section{Correlations and Taxonomic Units}

The histograms (Figs. 1-20) illustrate the differences in the distribution of correlations between species very well. In particular, there are great differences between Oryctolagus cuniculus and the other species in the 


\section{Table 3.}

Coefficients $r$ and $z$ of correlation between measurements of the lower cheek teeth of $\mathrm{Hy}$ polagus brachygnathus from Rębielice Królewskie (upper Pliocene) and Kadzielnia (early Pleistocene).

\begin{tabular}{|c|c|c|c|c|}
\hline & \multicolumn{2}{|c|}{$\begin{array}{l}\text { Hypolagus } \\
\text { Rębielice }\end{array}$} & \multicolumn{2}{|c|}{$\begin{array}{r}\text { brachygnathus } \\
\text { Kadzielnia }\end{array}$} \\
\hline & $r$ & $z$ & $r$ & $z$ \\
\hline & 1 & $\mathrm{n} \quad \mathrm{g}$ & $\mathrm{t} \quad \mathrm{h}$ & \\
\hline $\mathrm{P}_{3}-\mathrm{P}_{4}$ & 0.70 & 0.867 & 0.55 & 0.618 \\
\hline $\mathrm{P}_{3}-\mathrm{M}_{1}$ & 0.41 & 0.436 & 0.55 & 0.618 \\
\hline $\mathrm{P}_{3}-\mathrm{M}_{2}$ & 0.40 & 0.424 & 0.43 & 0.460 \\
\hline $\mathrm{P}_{3}-\mathrm{M}_{3}$ & 0.10 & 0.100 & 0.15 & 0.151 \\
\hline $\mathrm{P}_{4}-\mathrm{M}_{1}$ & 0.80 & 1.099 & 0.82 & 1.157 \\
\hline $\mathrm{P}_{4}-\mathrm{M}_{2}$ & 0.49 & 0.536 & 0.81 & 1.127 \\
\hline $\mathrm{P}_{4}-\mathrm{MI}_{3}$ & 0.45 & 0.485 & 0.49 & 0.536 \\
\hline $\mathrm{M}_{1}-\mathrm{M}_{2}$ & 0.83 & 1.188 & 0.80 & 1.099 \\
\hline $\mathrm{M}_{1}-\mathrm{M}_{3}$ & 0.09 & 0.090 & 0.22 & 0.223 \\
\hline $\mathrm{M}_{2}-\mathrm{M}_{3}$ & 0.10 & 0.100 & 0.22 & 0.223 \\
\hline & w i & d $\quad t$ & h & \\
\hline $\mathrm{P}_{3}-\mathrm{P}_{4}$ & 0.60 & 0.693 & 0.44 & 0.472 \\
\hline $\mathrm{P}_{3}-\mathrm{M}_{1}$ & 0.72 & 0.908 & 0.46 & 0.497 \\
\hline $\mathrm{P}_{3}-\mathrm{M}_{2}$ & 0.42 & 0.448 & 0.40 & 0.424 \\
\hline $\mathrm{P}_{3}-\mathrm{M}_{3}$ & 0.09 & 0.090 & 0.06 & 0.060 \\
\hline $\mathrm{P}_{4}-\mathrm{M}_{1}$ & 0.70 & 0.867 & 0.78 & 1.045 \\
\hline $\mathrm{P}_{4}-\mathrm{M}_{2}$ & 0.49 & 0.536 & 0.79 & 1.071 \\
\hline $\mathrm{P}_{4}-\mathrm{M}_{3}$ & 0.03 & 0.030 & 0.10 & 0.100 \\
\hline $\mathrm{M}_{1}-\mathrm{M}_{2}$ & 0.80 & 1.099 & 0.84 & 1.221 \\
\hline $\mathrm{M}_{1}-\mathrm{M}_{3}$ & 0.08 & 0.080 & 0.15 & 0.151 \\
\hline $\mathrm{M}_{2}-\mathrm{M}_{3}$ & -0.07 & 0.070 & -0.10 & 0.100 \\
\hline
\end{tabular}

correlations of tooth widths. L.europaeus, wild rabbit, and fossil $H$. brachygnathus have similar patterns of the distribution of correlations between the tooth lengths in the manible, but they differ in the height of correlations, especially in the case of the teeth which form a functional whole, i. e: $\mathrm{P}_{4}, \mathrm{M}_{1}$, and $\mathrm{M}_{2}$. L. timidus differs evidently from $L$. europaeus in the distribution of correlations of the widths in the upper dentition. Besides, L.timidus, in contrast with $L$. europaeus, has a greater number of stastistically significant coefficients for the widths of upper teeth. It shows a correlation between $\mathrm{P}^{3}$ and $\mathrm{M}^{1}$, which never occurs in L. europaeus, and between $\mathrm{P}^{2}$ and $\mathrm{P}^{3}$, which was found in none of the 

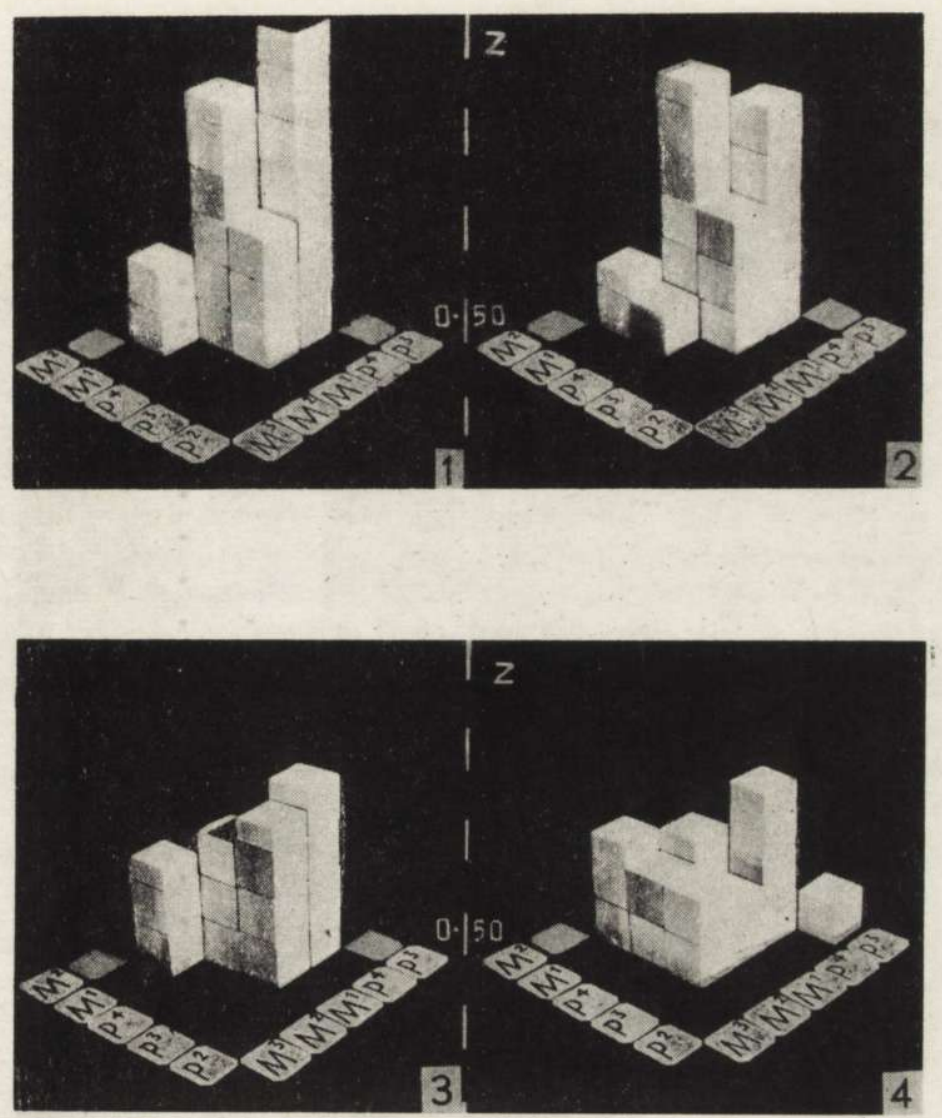

Figs. 1--4. Correlations of lengths of crowns in the upper cheek teeth of Lepus timidus from Arkhangel'sk (1), Lepus timidus from Vladivostok (2), Lepus europaeus (3), and Oryctolagus cuniculus (4). 

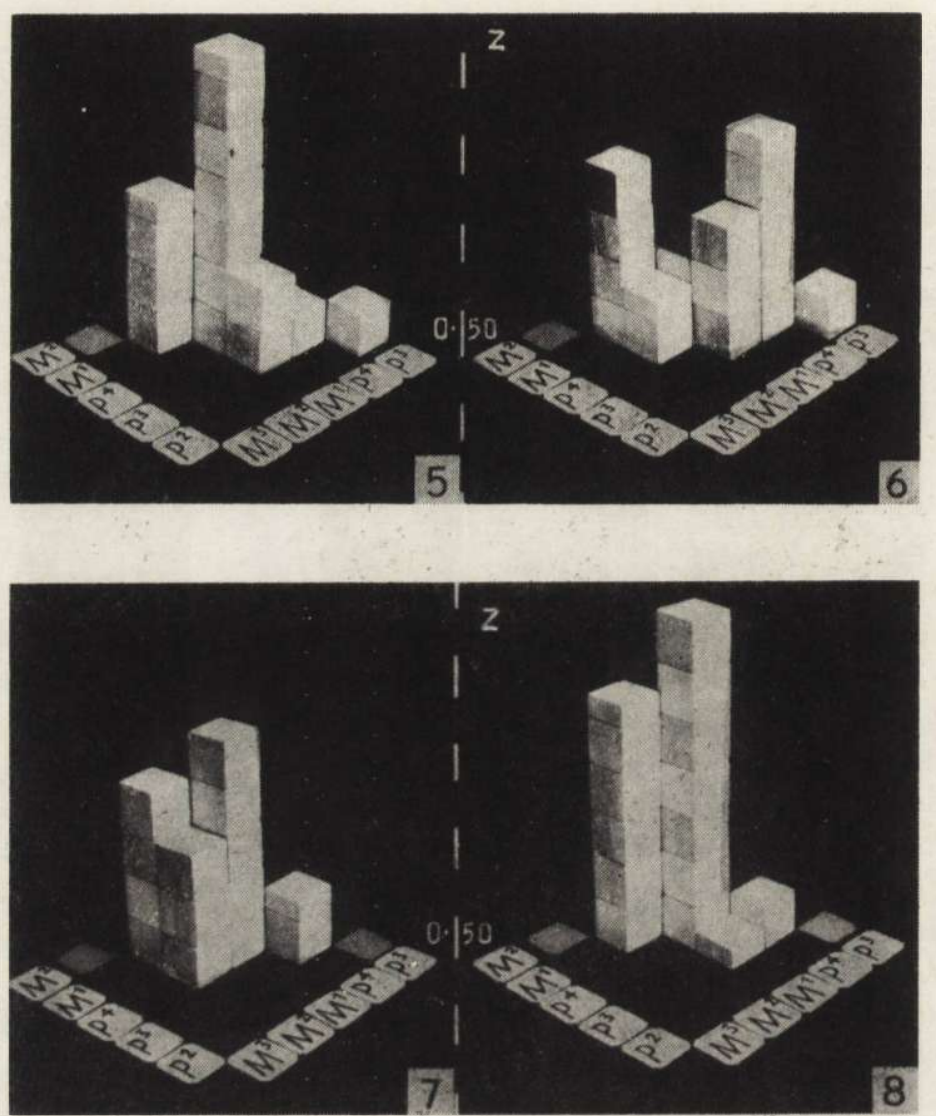

Figs. 5-8. Correlations of widths of crowns in the upper cheek teeth of Lepus timidus from Arkhangel'sk (5), Lepus timidus from Vladivostok (6), Lepus europaeus (7), and Oryctolagus cuniculus (8). 

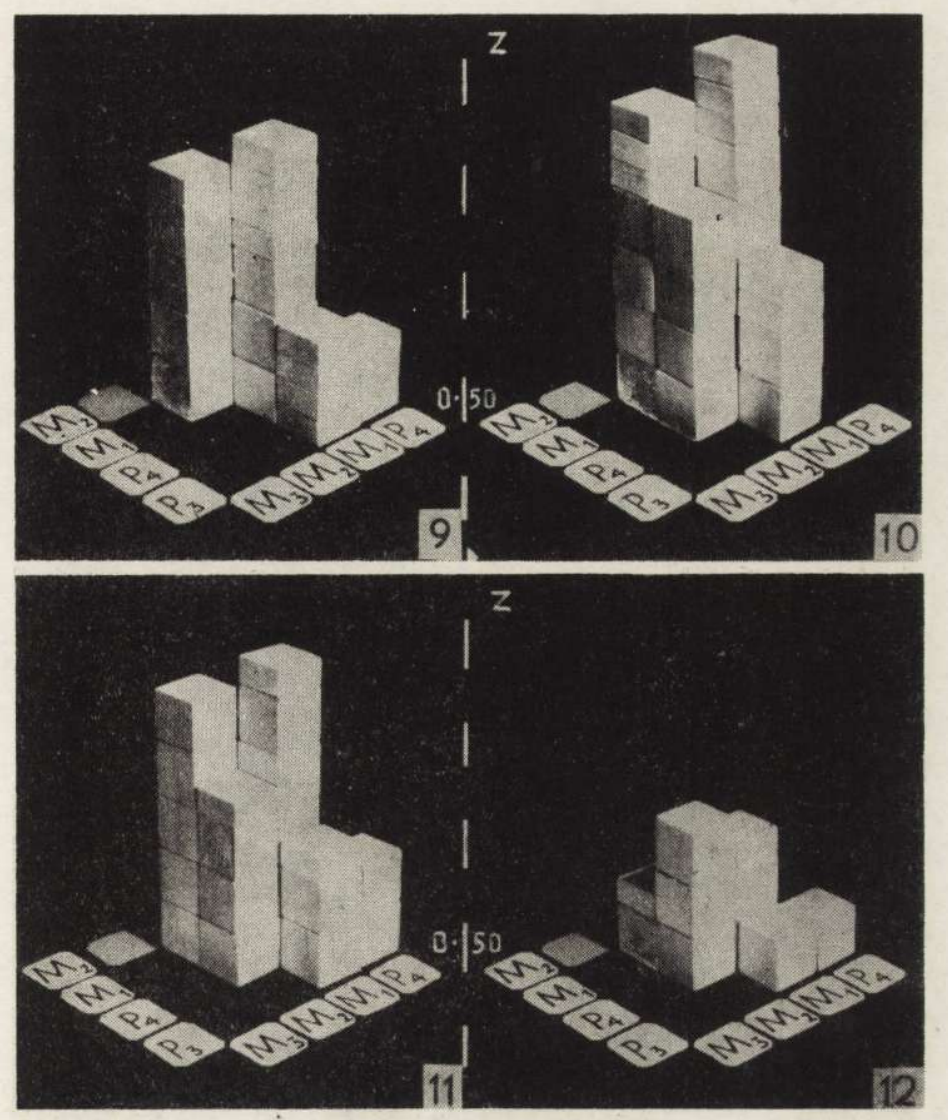

Figs. 9-12. Correlations of lengths of crowns in the lower cheek teeth of Lepus timidus from Arkhangel'sk (9), Lepus timidus from Vladivostok (10), Lepus europaeus (11), and Oryctclagus cuniculus (12). 

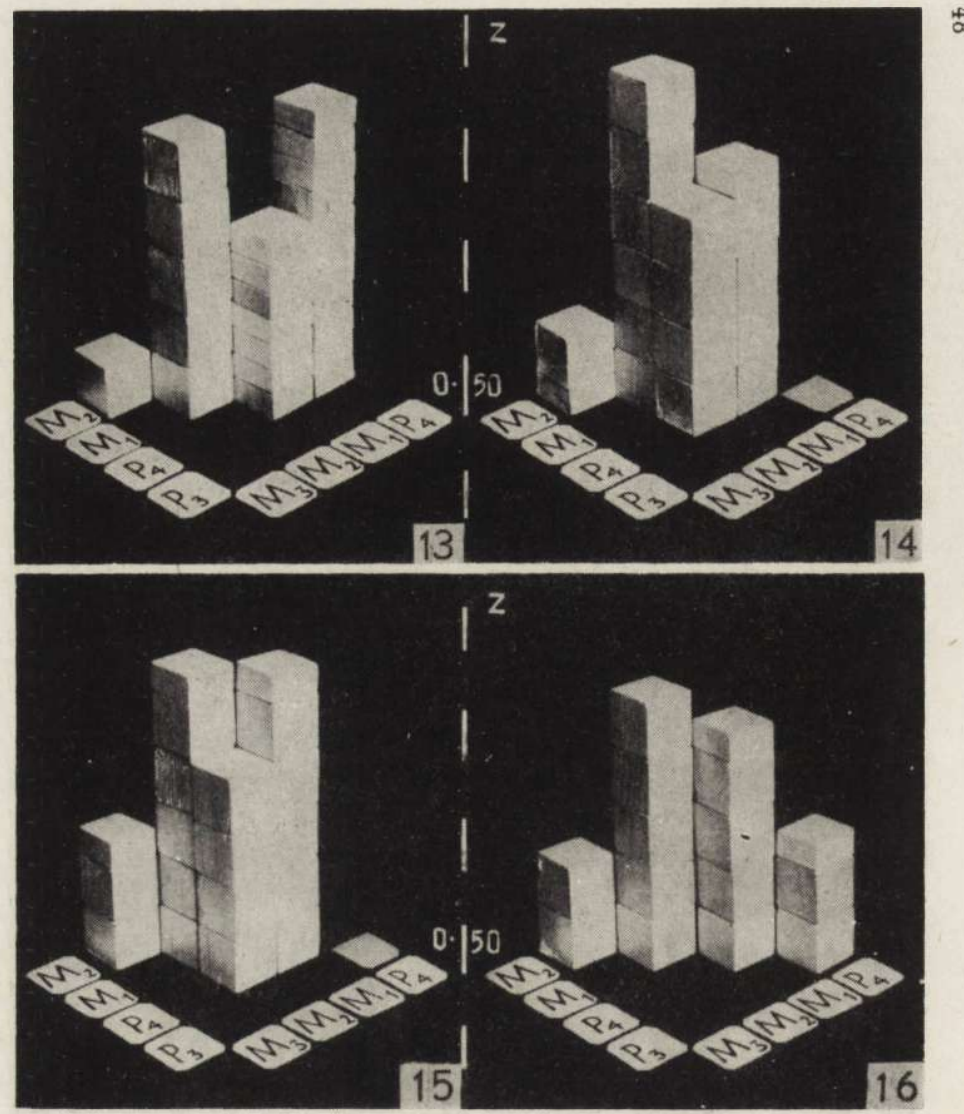

Figs. 13-16. Correlations of widths of crowns in the lower cheek teeth of Lepus timidus from Arkhangel'sk (13), Lepus timidus from Vladivostok (14), Lepus europaeus (15), and Oryctolagus cuniculus (16). 


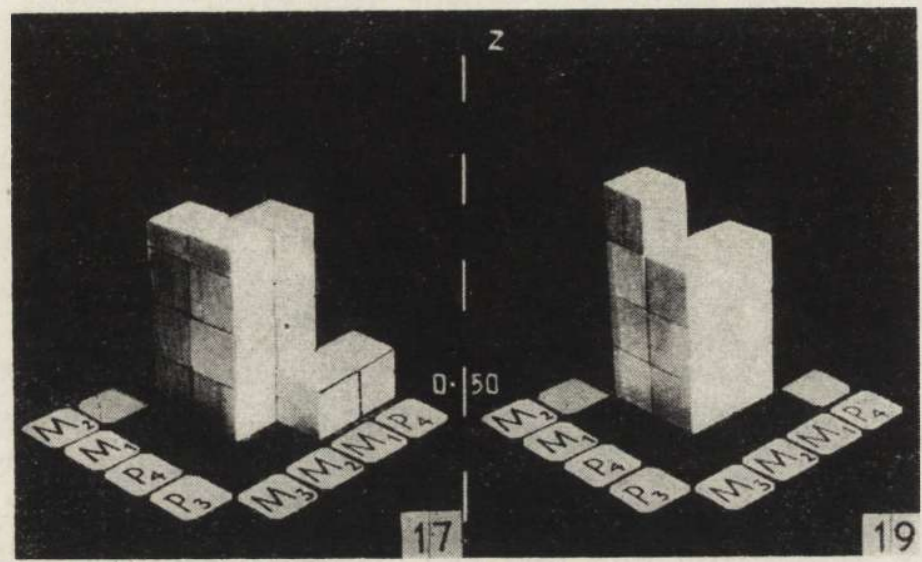

Figs. 17 and 18. Correlations of lengths of crowns in the lower cheek teeth of lossil Hypolagus brachygnathus from the Lower Pleistocene fauna of Kadzielnia (17) and from the Pliocene fauna of Rębielice Królewskie (13).

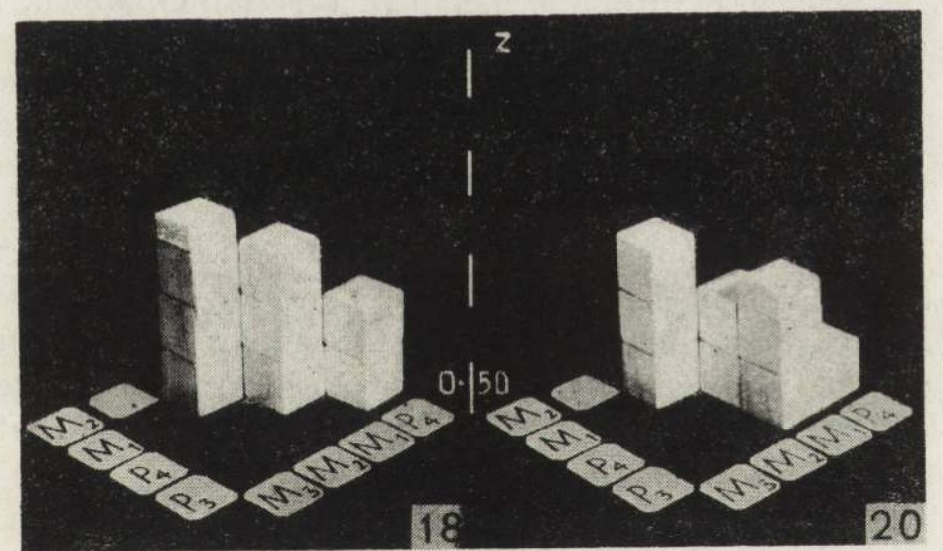

Figs. 19 and 20. Correlations of widths of crowns in the lower cheek teeth of fossil Hypolagus brachygnathus from the Lower Pleistocene fauna of Kadzielnia (19) and from the Pliocene fauna of Rębielice Królewskie (20).

Figs. 1-20. Histograms of coefficients of correlatiun for measurements of teeth converted to values $z$ of Fisher. Each section of the vertical axis corresponds approximately to the value of $0.20 z$. The area in which particular histograms are placed corresponds approximately to $0.50 z$. The histograms include only the statistically significant coefficients.

other species. However, L. timidus not only differs from the other species but also reveals some differentiation in its geographically remote populations. The appearance of correlation between $\mathrm{P}^{4}$ and $\mathrm{M}^{2}$, which occurs also in $L$. europaeus, was shown in the Vladivostok population of L. timidus. 


\section{Variation of Correlations with Time}

The samples of fossil Hypolagus brachygnathus from the upper Pliocene of Rębielice differ markedly from the similar samples of the early Pleistocene fauna of Kadzielnia. In addition to the three significant correlations of lengths between the directly neighbouring teeth (excepting $\mathrm{M}_{3}$, which is not correlated at all) there are also correlations of lengths, characteristic of O.cuniculus and L.europaeus, between $\mathrm{M}_{1}$ and $\mathrm{P}_{3}$ and between $\mathrm{M}_{2}$ and $\mathrm{P}_{4}$. The values of correlations are lower than in Lepus, which has already been commented on (S y c h, 1965). The widths of the lower teeth, too, show a considerable change in correlations, part of which are shifted on other teeth. It is characteristic that the connections of $\mathrm{P}_{3}$ with $\mathrm{P}_{4}$ and $\mathrm{P}_{3}$ with $\mathrm{M}_{1}$ decline with time and in the sample from Kadzielnia there appears a correlation between $\mathrm{M}_{2}$ and $\mathrm{P}_{4}$, the distribution of the correlation resembling that in $L$. europaeus and L.timidus. These changes are accompanied by a growth in the height of correlation, which, however, is not equal to the corresponding values in the genus Lepus.

\section{DISCUSSION}

Histograms, the interpretation of which seems easier than the interpretation of topographic fields of correlations figured by correlative isolines adopted by K u r té n (1953), were used to compare correlations. Moreover, the making-up of a histogram is not so laborious and presents no such difficulties as the correct interpolation of the intermediate values of the coefficient $z$ in the method of isolines.

It will be seen from the data presented above as well as from the data given by other authors who studied the correlations of different morphological characters (Terentev, 1960; Olson \& Miller, 1951; Kurtén, 1953; B erg, 1959; C a boń-R a c zyńska, 1964) that the study of the relations of morphological characters, which can be measured or univocally presented quantitatively, makes it possible to discover new characters, differing not only species but even distinct populations from each other, characters, the finding of which goes beyond the capacity of observation and visual comparison. In the present case the dentitions of all the species being compared (except $\mathrm{P}_{3}$ and $\mathrm{P}^{2}$ ) are, save for the minor differences in measurements, very much alike so that the distinction of species or even genera is extremely difficult. The correlations occurring between the measurements of teeth allow the finding of distinct taxonomic differences, which are the greater, the more remotely the forms under comparison are related. The differences between Oryctolagus cuniculus 
and the remaining species of the genus Lepus are greater than those between Lepus timidus and Lepus europaeus.

The high values of the coefficients of correlations in the dentition of leporids under examination can be arranged in groups, and then the teeth in these groups appear to form functional wholes. The correlations are grouped, to use the term of $\mathrm{T}$ e $\mathrm{r}$ e $\mathrm{n}$ t e v (1960), in pleiades. As it appears, the pleiades are not absolutely lasting formations. In B e r g's opinion (1959), the existence of correlation pleiades between some parts of an organism with the simultaneous lack of such pleiades between other parts is a manifestation of the independence of some evolutionary processes in the organism. According to this author, the appearance of pleiades is a sign of the emancipation of evolutionary processes in various parts of the organism in the evolution of a given line. Ols on \& M ille r (1951) claim that the correlation groups are of some biological importance and are formed, at least in part, under the influence of functional and evolutionary patterns. Thus, the study of correlations is closely connected with the knowledge of changes at the level of microevolution.

Out of the large number of measurements that can be made on a sample of population of a species, there are many which can be grouped on the basis of, for instance, the common function done by the part of organism being measured (after Ols on \& Mille r 1951, group - F). A group of highly correlated measurements (group $-p$ in the terminology of the above-mentioned authors) can be picked out of this total number of measurements. Another group (called group $-p F$ by Ols on \& M ille r l.c.) can be formed from these two groups so as to include elements which are highly correlated and, at the same time, stand in close relation on account of their common function. This last group is to be a basis for comparisons of species in their geographical, environmental as well as temporal or evolutionary aspects. In the present study the measurements of $\mathrm{P}_{4}, \mathrm{M}_{1}, \mathrm{M}_{2}$ and $\mathrm{P}^{3}, \mathrm{P}^{4}, \mathrm{M}^{1}, \mathrm{M}^{2}$ form distinct groups $p F$. Hence, it is possible to treat the above-described changes, taking place in $H$. brachygnathus in the course of time, as microevolutionary changes. The direction of these changes, as will be seen from the data presented in the tables and histograms, brought about the establishing of correlations resembling those in Lepus but of lower value, in the lower tooth-row. The genus Lepus, coexisting with $H$. brachygnathus for some time from the Pliocene on, was, as shown previously (S y c h, 1965), fitter for adaption to the environment than the other species, and this fact seems to have determined the extinction of $H$. brachygnathus, before the microevolutionary changes in its dentition reached the level of Lepus.

It is interesting that the original correlation between $\mathrm{P}_{3}$ and $\mathrm{P}_{4}$ of 
$H$. brachygnathus declined below the level of significance and that the specimens of $\mathrm{P}_{3}$ of this species from Kadzielnia and from the fauna of Kamyk near Częstochowa, younger than the fauna of Kadzielnia, besides an increase in the coefficients of variation for measurements, sometimes show the occurrence of additional structures in the form of enamel islands on the grinding surface of the tooth $(\mathrm{S} \mathrm{ch}, 1965)$. There seems to be a connection between the reduction in the dependence of the measurements of $\mathrm{P}_{3}$ on the neighbouring teeth and the increase in its morphological variability. This phenomenon can also be exemplified by $\mathrm{P}^{2}$, which, being poorly correlated with the other teeth, exhibits considerable morphological variation. Both these teeth are of the first importance in the systematics of the Leporidae.

On the other hand, $\mathrm{M}^{3}$, the measurements of which in the species examined are not correlated with the measurements of the neighbouring teeth, shows no tendency towards the changes described above, and what is more, in some lagomorphs it is missing at all.

Hence, it follows that the taxonomically important measurements can be determined by help of the coefficients of correlation grouped in pleiades. They are non-correlated measurements or measurements only weaikly correlated directly with others. This has already been demonstrated by the studies of correlation pleiades carried out by Cabon-Raczyńs k a (1964) on the skull of Lepus europaeus.

The appearance of correlations in tooth measurements, which were independent previously, e. g. $\mathrm{P}^{3}$ and $\mathrm{M}^{1}$, may be regarded as a continuation of the process of molarization of premolars. It is noteworthy that the process of molarization is more advanced in L. timidus than in L. europaeus. At the same time, L. trmidus reveals a distinct geographical differentiation in dentition, which cannot be perceived during normal observations.

The lack of the correlation of $\mathrm{M}_{3}$ and $\mathrm{M}^{3}$ with their direct neighbours in so far as their lengths are concerned was found also in the genus $\mathrm{Pe}$ romyscus (V a n Valen, 1962). In the leporids under study this lack is only partly compensated for by a slight correlation of the widths of these teeth. In Peromyscus the main role is played by the correlations of widths, the correlations of lengths being of lesser importance.

\section{REFERENCES}

1. B erg R. L., 1960: The ecological significance of correlation pleiades. Evolution. 14, 2: 171-180, Lancaster.

2. Caboń-R a c zyńska K., 1964: Correlations of skull measurements of Lepus europaeus P a l1 a s, 1778. Acta theriol., 8, 13: 207-216, Białowieża. 
3. K u rtén B., 1953: On the variation and population dynamics of fossil and recent mammal populations. Acta zool. fenn., 76: 1-122, Helsinki.

4. Ols o n E. C., \& M ille r R. L., 1951: A mathematical model applied to a study of the evolution of the species. Evolution, 5, 4: 300-325, Lancaster.

5. S impson G. G., R o e A., \& Le wontin R. C., 1960: Quanititative Zoology. $1-440$, New York.

6. Sy ch L., 1965: The fossil leporids from the Pliocen and Pleistocen of Poland. Acta zool. cracov., 10, 1: 1-105, Kraków.

7. Terentev I. V., 1960: Dalnejšeje razvitie metoda korelacjonnych plejad. Sb.: Primenene matem. metodov $\mathrm{v}$ biologii. Izdat. leningr. Univ.: 27-36, Leningrad.

8. V a le n van L. 1962: Growth fields in the dentition of Peromyscus. Evolution, 16, 3: $272-277$, Lancaster.

9. Whitele y M. A., \& Pe ars on K., 1900: Data for the problem of evolution in man. A first study of the variability and correlation in the hand. Proc. roy. Soc. 65 , London.

Received July 15, 1965.

Polish Academy of Sciences.

Institute of Systematic Zoology,

Cracow, Slawkowska 17.

\section{KORELACJE WYMIAROW ZĘBOW NIEKTORYCH ZAJĄCOWATYCH (LEPORIDAE) \\ O ZNACZENIU WSPOEEZYNNIKA KORELACJI W BADANIACH MIKROEWOLUCJI}

Streszczenie

Przeprowadzone zostało porównanie patternów korelacyjnych znalezionych przez obliczenie współczynników korelacji ( $r$ i $z$ Fish e r a) wymiarów zębów policzkowych u Lepus europaeus $\mathrm{Pa} 1 \mathrm{las}$, Lepus timidus Lin a e $\mathrm{s}$ z okolic Archangielska i Władywostoku, Oryctolagus cuniculus Lin na e us i u wymarlego Hypolagus brachygnathus Kormos z górnego pliocenu i wczesnego plejstocenu. Dla badanych gatunków obliczono wartości korelacji osobno dla pomiarów długości koron zębów, osobno dla ich szerokości. Najsilniejsze korelacje znaleziono między wymiarami środkowych zębów tak górnego jak i dolnego $\left(\mathrm{P}_{4}, \mathrm{M}_{1}, \mathrm{M}_{2} \mathrm{i} \mathrm{P}^{3}, \mathrm{P}^{4}, \mathrm{P}^{1}\right)$. Ważne taksonomicznie zęby $\mathrm{P}_{3}$ i $\mathrm{P}^{2}$ wykazują stosunkowo niezbyt wysokie korelacje z pozostałymi, nawet sąsiednimi zębami. U gatunków współczesnych nie znaleziono zależności długości $\mathrm{M}_{2}$ i $\mathrm{M}_{2}$, stwierdzono tylko związek szerokości tych dwóch zębów. U Hypolagus brak w ogóle korelacji między nimi. Pomimo, że zęby badanych gatunków są do siebie bardzo podobne, za wyjątkiem $\mathrm{P}_{3} \mathrm{i} \mathrm{P}^{2}$, to ich patterny korelacyjne różnią się wyraźnie. Wykazano nawet różnice między odleglymi od siebie geograficznie populacjami: Lepus timidus z regionu archangielskiego i władywostockiego. Struktura patternu korelacyjnego może zmieniać się w czasie: Hypolagus brachygnathus pochodzący z I interglacjału Kadzielni w Kielcach uległ dostrzegalnym zmianom od starszego, górnego pliocenu Rębielic Królewskich. Zmianom roz- 
mieszczenia korelacji towarzyszy tu również wzrost ich wysokości. Wydaje się, że istnieje związek między zmniejszaniem się zależności wymiarów $\mathrm{P}_{3}$ od sąsiednıch zębów, a zwiększaniem się jego morfologicznej zmienności; zjawisko to obserwować można na przykładzie $\mathrm{P}^{2} \mathrm{u}$ kopalnego Hypolagus brachygnathus. Wydaje się, że przy pomocy współczynników korelacji grupowanych w plejady można ustalać pomiary ważne taksonomicznie. Byłyby to pomiary nieskorelowane, lub tylko słabo związane bezpośrednio $\mathrm{z}$ innymi. Badanie zmian mikroewolucyjnych możliwe jest w grupach funkcjonalnie pokrewnych i równocześnie wysoko ze sobą skorelowanych. 